\title{
STRATEGIC AFRO-MODERNISM, DYNAMIC HYBRIDITY, AND BEBOP'S SOCIOPOLITICAL SIGNIFICANCE
}

\author{
Cynthia R. Nielsen
}

\begin{abstract}
Purpose - I argue that one can articulate a historically attuned and analytically rich model for understanding jazz in its various inflections. That is, on the one hand, such a model permits us to affirm jazz as a historically conditioned, dynamic hybridity. On the other hand, to acknowledge jazz's open and multiple character in no way negates our ability to identify discernible features of various styles and esthetic traditions. Additionally, my model affirms the sociopolitical, legal (Jim Crow and copyright laws), and economic structures that shaped jazz. Consequently, my articulation of bebop as an inflection of Afromodernism highlights the sociopolitical, and highly racialized context in which this music was created. Without a recognition of the sociopolitical import of bebop, one's understanding of the music is impoverished, as one fails to grasp the strategic uses to which the music and discourses about the music were put.
\end{abstract}

\footnotetext{
Music and Law

Sociology of Crime, Law and Deviance, Volume 18, 129-148

Copyright $(\mathbb{C} 2013$ by Emerald Group Publishing Limited

All rights of reproduction in any form reserved

ISSN: 1521-6136/doi:10.1108/S1521-6136(2013)0000018009
} 
Design methodology/approach - I engage in an interdisciplinary study of jazz via analyses and commentary on selected texts from several scholarly disciplines.

Findings - To acknowledge the hybridity and social construction of jazz esthetics in no way nullifies the innovations and leadership of African American jazz musicians whose artistic contributions not only significantly shaped modern jazz in the mid-twentieth century but also whose musical voices continue to sound and set esthetical standards in contemporary expressions of jazz (and beyond).

Originality and value - My chapter is highly interdisciplinary, bringing philosophical explanations of race, discourse, and the ontology of music into conversation with numerous sociological and (ethno)musicological insights about jazz.

Keywords: Afro-modernism; hybridity; jazz esthetics; bebop; race; jazz discourses

\section{INTRODUCTION}

In this chapter, I argue that if race is socially constructed (and I believe it is), then jazz esthetics must also be understood and more carefully articulated as socially constructed. Both race and jazz esthetics are conditioned by cultural, political, legal, economic, and myriad other social narratives, discourses, and practices. As social realities, neither race nor African American or European musical styles emerge from an immutable essence or consist in a fixed set of characteristics purporting to define (once and for all) what it is to be black or authentically "black" bebop or "white" cool jazz. An analysis of the complex social ontology of jazz esthetics reveals both the hybridity of jazz and provides a model for understanding dynamic identity. Although a historical and thoroughly social reality, jazz (and by extension this applies to European classical and other musical genres, styles, and inflections) communicates something about the social context, history, and the pre-history in which it is created and performed. For example, the bebop of the 1940s-1960s is of course intimately connected to the histories and struggles of African Americans, both of which were played out and developed in relation to whites of various political, religious, national, international, social, and esthetic sensibilities. ${ }^{1}$ In short, my claim 
is that music (and bebop in particular), like other social realities, is an evermorphing mulatto.

To claim that categories such as race, blackness, whiteness, black esthetics, and the like are socially constructed is in no way to deny the stark differences in lived experience of various ethnic groups - in particular, the numerous injustices experienced by blacks due to racist practices and residing in a racially structured society that exploited blacks and benefited whites. Nor is it to deny that specific musical characteristics at particular historical moments are often associated with Afro (black) or Euro (white) musical styles and esthetics. Lastly, to argue for the social construction of esthetical categories by no means negates the decisive, formative contributions, innovations, and leadership of musicians such as Dizzy Gillespie, Charlie Parker, Miles Davis, and countless other African American artists whose "musical signatures" both significantly shaped modern jazz in the mid-twentieth century and whose voices continue to sound and re-sound in current expressions of jazz.

Although Afro-modern esthetics and European classical esthetics are not fixed essences but like "race" are dynamic, historical, social realities, they nonetheless exhibit a provisionalfixity or fluid identity. This dynamic identity or ontology is shaped and maintained by historically specific sociopolitical structures, as well as particular discourses and practices. Moreover, the affirmation of the historical and constructed character of various musical esthetics in no way negates our ability to identify their (historically shaped and always permeable) characteristics and features. Stated otherwise, musical esthetics are socially conditioned and highly fluid realities; yet such fluidity coexists with a "staying power" or nonpermanent fixity allowing one to identify (via musical theoretical analysis and aural skills of various degrees) a clearly recognized esthetic, style, or genre. Thus, particular esthetics and styles such as blues, Afro-modernism, French Impressionism (as a style within European classical music), tonal serialism, etc., can congeal into something quite recognizable and transferable and yet remain open to alterations and (re)harmonizations creating new (future) styles.

Here it is instructive to draw upon Michel Foucault's notion of historical a prioris. According to Foucault, as the qualifier emphasizes, historical a prioris are historically conditioned structures or rules that make possible the emergence of various kinds of knowledge and discourse. In addition, they define by way of fulfillment requirements what counts in a particular historical epoch as valid or legitimate expressions of knowing, being, or doing. However, unlike Kantian a priori conditioning structures, Foucauldian 
historical a prioris are themselves subject to change over time. In other words, Foucault's structures are mutable and historically particular - or as he might put it, episteme-specific. Yet given their function as conditioning structures that make it possible for certain kinds of discourse, knowledge, and practice to appear, they change less frequently and can last for decades and even centuries, thus allowing various styles, traditions, and recognizable esthetical expressions to come into focus, gain momentum and esteem, and, as it were, take on lives of their own.

By employing Foucault's insights regarding historical conditioning structures and the analyses of ethnomusicologists and other scholars of African American music cognizant of race and musical esthetics as socially constructed realities, I argue that one can articulate a historically attuned and analytically rich model for understanding jazz in its various inflections. That is, on the one hand, such a model permits us to affirm jazz as a historically conditioned, ever-open dynamic hybridity. On the other hand, to acknowledge the hybridity and fluidity of jazz in no way negates our ability to identify discernible features commonly recognized as constituting, for example, Afro-modernist jazz inflections such as bebop, as well as multiple other musical styles and esthetics. ${ }^{2}$ Of course, music-making as creative human activity takes place in specific historical contexts. Hence, not only multiple musical streams but also sociopolitical, cultural, legal, and economic structures and practices influence and condition all types of music-making.

Given America's long history of racism - and in no way denying that definitive emancipatory gains had been won - unjust racist structures and practices remained entrenched throughout the twentieth century (and many, no doubt, continue today). Such racialized structures, which privileged whites, created significant barriers for African Americans in their pursuit of equal recognition and opportunities to live a life of human flourishing. Although black jazz musicians were often recognized by the dominant society for their extraordinary talents, such recognition existed simultaneously with "Whites Only" signs. In other words, even when black musical talent was publicly affirmed and lauded, discrimination in the world of music was just as prevalent as discrimination in other social and economic spheres, making it difficult for African American musicians to earn a living wage. Moreover, white ownership of clubs, hotels, concert halls, and record companies created a power differential, which when operative within a racialized society, meant that white musicians often received the best performing venues with respect to both monetary and cultural capital. In contrast, blacks were given less prestigious performance 
sites and regularly received inadequate and incommensurate pay for their artistic creations and musical performances (see, e.g., Monson, 2007, Chapter 2). To bracket this history in the study of jazz is to fail to hear what the music says and to fail to recognize the power of music - even instrumental music - both to (re)narrate collective (and personal) identity and to sound a polyphonic, multi-layered sociopolitical critique. As Guthrie P. Ramsey puts it, "the political import of bebop could not be (and was not) ignored. [...] these were signifying texts, indeed" (Ramsey, 2003, p. 108; see also, Thomas, 1995; Kelly, 1997).

I begin by explaining how particular American legal discourses and social practices constructed "blackness" and helped to establish artificial and harmful black-white binaries. I then focus on jazz's mixed heritage. In this section, I especially emphasize the sociopolitical dimensions of jazz. The notion of music as a site of struggle is a natural segue into an exploration of bebop as an instance of Afro-modernism. Having highlighted the hybridity of bebop and its sociopolitical import, I then examine how traditional Western discourses privileging the composer over the jazz improviser worked in conjunction with early copyright laws to disadvantage the latter economically and socio-culturally. Following the discussion of bebop as a strategic inflection of Afro-modernism, I turn to an analysis of Foucault's work on historical a prioris and the acceptability conditions of discourse, as well as Monson's analyses of jazz discourses and her notion of sonic $\operatorname{signifyin}(\mathrm{g})$.

\section{LEGAL CONSTRUCTIONS OF RACE: THE ONE-DROP RULE AND THE CONSTRUCTION OF (FALSE) BINARIES}

As students and scholars of race and African American history observe, the one-drop rule plays an especially important and rather idiosyncratic role in the legal construction of blackness in the history of the United States. Although the one-drop rule was an "unofficial" social practice during the years of chattel slavery, it was employed regularly as a way to maintain a strict black-white divide. Children who were the offspring of white and black sexual unions - many of which were born as a result of white masters raping their black female slaves - presented a problem for the dominant society. The hybridity of the mulatto child posed, on the one hand, an ontological challenge to the artificiality of the white-constructed color line 
and a potential threat to the social, political, and economic advantages created by this one-sided system. To deal with this categorization "problem," Southern states created and applied the one-drop rule: anyone possessing "one drop" of so-called black blood or any trace of African ancestry was considered black. Consequently, biracial children of slave women were deemed slaves at birth and thus became the property of their white masters - masters who were also their fathers.

However, the one-drop rule did not disappear after slavery was abolished. In fact, during the Jim Crow era, the one-drop rule became codified as law (see, e.g., Khanna, 2010, esp. 98-101). As expressed in its nineteenth-century manifestation and working hand-in-hand with Jim Crow legislation, the one-drop rule proclaimed that any person with "traceable black ancestry" was considered legally black. Tellingly, the percentage or trace of black ancestry legally constituting an individual as black varied over time and from state to state. For example, until 1910 in Virginia, a person was classified under law as "colored" if he or she had one-quarter or more African ancestry; however, from 1910 to 1924 Virginia decided to "lower" the requirement for blackness to include those with one-sixteenth black ancestry (Monson, 2007, p. 8). Following this period (post-1924), Virginia declared that in order for a person to be judged legally white, he or she must possess no trace of African ancestry - not even "one-drop" of "black" blood (Monson, 2007, p. 8).

Many who were one-eighth black or less exhibited none of the outward markers associated with African or African American descent. In other words, they could "pass" as white since they were extremely light-skinned; and skin color, given its visibility, tended to be the outward "sign" most heavily scrutinized. Since the requirements of the one-drop rule varied from state to state, those who were legally classified as black in one state might be judged white in another. Thus, the act of crossing a state border could (at least given the "logic" of the theory) change one's racial classification and significantly impact one's life-course. In addition, those who in a former period were not considered "colored" because they were only onesixteenth black - were they still alive - would be legally deemed black in a later period when the African ancestral percentage-requirements became stricter. These examples highlight the mutability of race as well as the ways in which legal constructs and social practices and discourses combine in order to shape and produce race for political, economic, and other purposes. Moreover, what was in fact a wide color spectrum and a diverse mixed heritage, including not only black and white mixed ancestries but also black and Native American as well as black and Native American and 
European and Native-American combinations, was forced into an unnatural black-white binary. What existed in reality as a mixed heritage or hybridity was presented as a rigid, fixed, impenetrable dichotomy. As Monson explains, the purpose of the one-drop rule was to preserve and uphold "white purity and domination by assigning intermixture to the legally subordinate category. [...] The strict binary racial classification of Jim Crow attempted to legislate a clear division in a society that was far more hybrid than segregation laws admitted" (Monson, 2007, pp. 8-9). ${ }^{3}$

Along similar lines, discourses about jazz have arisen that mirror these artificial, binary white-black classifications and thus imply and perpetuate the false notion that a fixed racial essence informs musical esthetics and styles. Utilizing the insights from multiple scholars and disciplines, I reject this overly rigid, ahistorical characterization of musical esthetics. In its place, I present a historically sensitive understanding of jazz - focusing mainly on bebop - that, on the one hand, takes seriously the contributions and innovations of canonical African American musicians such as Dizzy Gillespie and Charlie Parker, yet on the other hand, recognizes the hybridity of music-making and the dynamic ontology of music itself. In addition, my model embraces the notion of music as a site of struggle and a means for collective and personal (re)narrations and sociopolitical censure. In the following section, I discuss (1) the ontology of jazz - its hybridity and dynamic identity - and (2) the sociopolitical dimensions of jazz both musically (i.e., the music itself) and discursively (i.e., the discourses about jazz).

\section{JAZZ'S MIXED HERITAGE: POWER DIFFERENTIALS AND STRATEGIC DISCURSIVE AND SONIC SIGNIFYIN(G)}

In a recent short essay, Ronald Radano highlights the power of slave music to exceed the controlling, exploitative grasp of white slave owners (2010, p. 366). How is this possible? How can that which is produced by the master's "property" somehow free itself from the master's chains? Slaves, of course, were not "things," and their ability to create beautiful, profoundly moving music underscores the absurdity, greed, and self-deception upon which chattel slavery was built. Humans, not inanimate objects, create music. ${ }^{4}$ In other words, the ability to compose music not only for esthetic but also for strategic sociopolitical purposes - whether bebop, Baroque, avant-garde, or hip hop - is a distinctly human capacity. As complex social, 
intellectual, affective, and creative acts, music-making and the enjoyments of music are human activities that, among other things, allow our stories to be told and our sufferings and joys to be heard and shared. Moreover, like great works of literature and philosophy, music carries within itself a multiplicity of voices - past and present - creatively harmonized and crafted into an identifiable form and content, yet always open to future (re)harmonizations and (re)interpretations. As a social and cultural artifact, music often arises from sites of struggle. For example, black spirituals and much of the blues and jazz styles created and performed by African Americans was birthed amid intense social and political struggle. Given this racialized and exploitative social context, music-making was not a mere autonomous, art-for-art's-sake activity. As Ramsey explains, "the cultural politics of African American music has developed within powerful ideologies surrounding race. For that reason, the principle of artistic autonomy could not develop within black culture in the same way as it had with regard to the Western art music tradition" (Ramsey, 2003, p. 109). This is neither to disown the modernist impulses and influences on jazz and bebop in particular nor to deny bebop's status as art music; rather, it is to claim that in addition to its esthetic value as a human artistic work, music-making and performance functioned as powerful sociopolitical (nonviolent) "weapons," challenging dominant narratives and providing a way for African Americans to re-narrate a white-scripted history while leaving their esthetic mark on American culture (and beyônd).

Just as slaves intentionally engaged in distinctly human creative acts and often for strategic, counter-hegemonic purposes, African American jazz musicians of the 1940s-1960s likewise gifted American culture with landmark musical contributions, many of which carried intentional social and political messages. Even a musician such as Thelonious Monk, who is often labeled as an apolitical jazzman, was well aware of the daily racial injustices blacks experienced. Monk, for example, devoted his time, talent, and money to the African American struggle for civil rights and economic equality through benefit concerts and other venues. In other words, there were many different ways in which a jazz musician might express his or her allegiance to and participation in the civil rights movement. Some musicians such as Max Roach and Abby Lincoln were outspoken figures who composed specific musical compositions with conspicuous political protests (see, e.g., Monson, 2007, Chapter 5). ${ }^{5}$ Others believed that by dedicating themselves to the creation of outstanding, ground-breaking music, the excellence of their artistic contributions would help to expose the absurdity and falsity of long-held negative assessments of African Americans' 
intellectual, moral, and esthetic capabilities. Yet even with this latter approach where the focus is on the music itself, one of the intended and anticipated outcomes is to participate in the communal struggle of dismantling unjust structures and re-writing racialized narratives in order to establish a more just and equal social, economic, and political standing for African Americans.

America's history of unjust and exploitative treatment of African Americans - from the Jim Crow South color-coded laws to the Northern ghettos, urban riots, and the various protests and activities that led to the passage of the Civil Rights Act of 1964 - significantly impacted the lives of African American jazz musicians and their artistic creations. For example, commenting on the jazz modernism of the 1940s, Eric Lott observes, "it is impossible to absorb the [be]bop attack without its social reference" (1988, p. 597). Of course, individual musicians channeled their frustration, anger, disappointment, and countless other emotions differently. Some chose the route of open protest via association with black nationalist or other political groups dedicated to dismantling racial, sociopolitical, and economic inequality. As mentioned earlier, others chose different strategies and expressed their frustrations and protests primarily through their music. For example, scholars have commented on how African American jazz musicians, given their unequal economic and social treatment in the music world, intentionally created complex musical harmonies performed at blinding tempos that allowed them to display their virtuosity while leaving their white counterparts at times baffled and unable to compete (see, e.g., Lott, 1988). This situation, of course, was not the case for all white jazz artists, as some were quite capable of navigating bebop's extended harmonies and lightning tempos. However, the interracial tensions and societal structural inequalities that African Americans jazz artists experienced undoubtedly impacted their creative compositional responses to the music's evolution and oft-associated key characteristics. Commenting on bebop in general as well as Charlie Parker's contributions and artistic participation in the broader African American struggle for equality, Lott states: "Bebop was about making disciplined imagination alive and answerable to the social changes of its time. [...] jazz was a struggle which pitted mind against the perversity of circumstance, and that in this struggle, blinding virtuosity was the best weapon" (1988, p. 597). In short, one might say that the racialized social, political, and economic contexts served as at least partial conditions making possible some of the important harmonic and other musical innovations and characteristic features of bebop. 
Along similar lines, consider the by-and-large positive experiences of African American jazz musicians such as Dizzy Gillespie and Charlie Parker as they toured and spent time in Europe (see, e.g., Monson, 2007, p. 86). Quite unlike their thoroughly racialized and exploitative socio-economic context in the United States, Europe presented them with a context in which they were not only admired for their artistic abilities - which was the case in America among certain jazz connoisseurs and aficionados - but also, and more importantly, where they were treated as fellow human beings: moral and intellectual equals worthy of respect and dignity. This favorable treatment African American musicians experienced while performing in Europe serves as an important backdrop for understanding the complex relation that black jazz musicians have had with the modernist or "high art" tradition.

\section{Bebop as a Hybrid Inflection of Strategic Afro-Modernism}

Although it shares several features and impetuses with so-called classical modernism - for example, formal innoyations and reaching new heights of expressivity - Afro-modernism of the mid-twentieth century (roughly 1940-1960) manifests distinctive characteristics arising from and related to the particular sociopolitical and economic struggles of African Americans. Guthrie P. Ramsey highlights one aspect of Afro-modernism as the process of African Americans grappling with their place in the modern industrialized, capitalistic world and working out their thoughts, feelings, and stances artistically and collectively (2003, p. 97). Whether we find Afromodernist overtones expressed via bebop's structural expansions, exceedingly complex harmonies, extended and virtuosic improvised solos, or hybrid African, African American, and Afro-Cuban musical styles, one must also take into account the tension-ridden, racially conflicted sociopolitical and economic context from which the music emerged. ${ }^{6}$ To illustrate, consider my earlier statement that it is a mistake or at least an incomplete characterization to describe bebop as chiefly concerned with the principle of artistic autonomy. Granting this claim and considering the racialized context in which it operated, bebop artists and advocates strategically employed a modernist narrative of autonomy in order to challenge and subvert stereotypical depictions of black musicians as mere entertainers (for whites). In the process of deconstructing white-imposed narratives of what a black musician is or ought to be, bebop artists self-consciously appropriated modernist tropes and discourses to construct their own 
personal and collective Afro-modernist stories. Yet as Ramsey explains, not only do the new black-scripted modernist narratives proclaim that bebop was neither "dance music" nor "conceived for mass consumption," it also asserted that bebop was "not designed for traditional 'high brow' concert audiences" (Ramsey, 2003, p. 106).

Although it drew upon past sources - from both the Afro and Euro traditions - and was thus clearly hybrid in nature, bebop as an Afromodernist art form was something new. Having broken down the traditional rigid barriers and antagonisms between so-called "high" art music and "folk" music, as well as discourses claiming that art music has no political import, bebop opened up a new musical horizon whose artistic excellence carried sociopolitical substance. As Henry Louis Gates Jr. might put it, bebop musicians' (re)harmonizations and transformations of musical "texts," traditions, and discourses were signifin(g) acts. That is, not only the discourses about bebop but also the musical pieces themselves are instances of "black double-voicedness" and repetition with a "signal difference" intentionally and strategically enacted to speak to social, political, and economic issues (1988, p. 51; see also, Chapter 2). In short, bebop's harmonic, rhythmic, and structural complexity coupled with its blinding, virtuosic improvised solos and distinctive grooves combine to create an expression of black art music or strategic Afro-modern jazz, whose innovations and contributions, given the racialized context in which they emerge, carry with them multi-layered sociopolitical significations. To imagine that African American bebop musicians were simply performing and creating works for art's sake in line with the Western art music tradition's discourses on artistic autonomy is to ignore the harsh, racialized reality and lived experience of African Americans in the U.S. history and to conceive of music as an ahistorical artifact untouched by its particular sociopolitical and cultural contexts.

Although, as mentioned earlier, bebop artists were, on the one hand, decidedly not creating music for mass consumption or for traditional "high brow" audience. Moreover, like other highly skilled professionals, they desired and rightfully expected a living wage. However, the complex of American racism and modern capitalism created a particularly constricting and slanted framework - a framework whose laws, discourses, and practices privileged (white) copyright owners while diminishing music-makers, especially black improvising music-makers. Before concluding this section, let me illustrate how bebop as an inflection of strategic Afro-modernism worked within and against these slanted structures and discourses in order to resist and transform the commodifying practices of capitalism - and of 
course simultaneously struggled against racist (il)logic. ${ }^{7}$ From a musictheoretical perspective one could make a strong argument that composition and improvisation are emphases on a single continuum and thus differences between the two are more matters of degree; however, in the socioeconomic sphere the difference between the socially prestigious label, "composer," and the socially stereotyped label, "improviser," is stark. ${ }^{8}$ The traditional Western notion privileging the composer over the jazz improviser or the "mere" performer per se views the composer as the sole or primary originator and author of the musical piece. This understanding of what a composer is and does is intimately tied to the development of musical notation. A musical score takes the live, dynamic performed music and reduces it to signs on a page. From one perspective, such technologies are completely understandable, legitimate, and even helpful to the process of preserving and transmitting music to subsequent generations. From another perspective, these fixed (silent) signs make it easy to ascribe ownership and thus creative primacy and economic privileges to specific individuals. Within the framework of modern capitalism and its drive to commodify, ownership and copyright laws go hand in hand. Since the improviser is viewed as a mere performer, a conduit or tool, his or her significant contribution - or better co-creation - that transforms the silent signs on a page into (actual) music is diminished. Moreover, this diminishment is made manifest in the economic realm. ${ }^{9}$ As Scott DeVeaux observes, even as the artistic talent of a jazz legend such as Charlie Parker is publicly recognized by musicians, critics, and jazz fans across the ethnic spectrum, nonetheless "in a music industry designed to funnel profits to the owners of copyrights, improvisers have found themselves in an anomalous and frustrating position. The history of jazz can be read, in part, as an attempt by determined musicians to close the gap between artistic ambition and economic reward" (DeVeaux, 1997, p. 9).

In fact, as many scholars have pointed out, the original Copyright Act of 1909 itself presupposes that only musical expressions that correlate to a written composition or score qualify as copyrightable material; thus the composer, rather than the performer, is given artistic preference, which, in a capitalistic system, translates into economic privilege. Prior to the 1970s' amendments to copyright laws, recorded versions or improvised performances based on but exceeding and often transforming written scores were not granted a legal copyright-protection status. ${ }^{10}$ Consequently, songwriters (composers) and publishers received the bulk of royalty payments, whereas performers (improvisers) were typically paid a one-time fee and their share of the royalties was significantly less (Monson, 2007, p. 336). 
Monson provides an excellent example of how such laws favored the composer/songwriter economically and continued to reinforce the idea that the composer/songwriter is the sole musical creator, whereas the improviser/performer is simply a conduit giving expression to the composer's musical intentions. Take, for instance, Miles Davis' 1956 recording of "My Funny Valentine" by Rogers and Hart. Here we have an improvised performance that includes significant harmonic and rhythmic additions, as well as masterful improvised solos creating a new form that many deem superior to the original version. However, as Monson notes, "Davis's unique version of the tune was not copyrightable." Moreover, not only did the songwriters and publisher receive the mechanical royalties, but when Davis's version was heard on radio or TV, additional broadcast royalties were earned by the songwriters and publisher and collected by the American Society of Composers, Authors, and Publishers (ASCAP) (Monson, 2007, p. 30). Such a system clearly exhibits an unfair economic benefit for (mainly white) composers, publishers, and those controlling the radio and television broadcasting industry,

Having discussed bebop's hybrid character, its strategic deployments as an expression of Afro-modernism, and the problematic aspects of the early twentieth-century copyright laws, I turn now to a more technical discussion about discourses. Specifically, I shall bring Foucault's analyses of conditioning structures, discourses, and acceptability conditions into conversation with Monson's work on jazz discourses and sonic signifyin(g).

\section{Foucault on the Social Layers and Acceptability Conditions of Discourses}

As Foucault has taught us, what surfaces as the prevailing discourses of a particular period in no way exhausts the reality or complexity of phenomena. In his work, The Archaeology of Knowledge, Foucault concerns himself not merely with traditional philosophy of language inquiries such as what counts as a true or false statement. For Foucault, an equally important question is: what are the conditions that make possible a statement or a discourse showing up so that it actually counts at a particular moment in history as a statement or discourse "worthy" of being judged as true or false? In other words, Foucault's analyses focus upon the circumscriptive background "space" that allows various discourses and statements to emerge in the first place. This circumscriptive space, or to use Foucault's terminology, the historical a prioris of various epochs, consists of sets of rules or standards that determine not which statements are veridical (dire 
vrai) but which statements are in the true (dans le vrai) (see also, Thompson, 2008, esp. p. 12).

Stated from a slightly different angle, to be in the true is inextricably linked with what Foucault calls the "acceptability" of truth and the "acceptability of a system" such as the carceral system or the healthcare system (see, e.g., Foucault, 2007, p. 61). Acceptability conditions speak of the conditions that allow a statement to show up as a recognizable statement while bracketing questions of the statement's truth-value. Thus, for Foucault, a proposition that has already been received by a particular discipline such as music, physics, biology, and so forth is a proposition dans le vrai; however, its status as dans le vrai does not equate with its truth; it may in fact be received as true yet proven false at a later date. Once we recognize Foucault's focus on the acceptability conditions of propositions and discourse - rather than on the truth-value of statements we can better understand his claim: "[a] discipline is not the sum total of all the truths that may be uttered concerning something; it is not even the total of all the truths that may be accepted, by virtue of some principle of coherence and systematization" (Foucault, 1972, p. 223). Take, for example, the former (pseudo-)scientific discourse concerning race as a bio-behavioral essence determinative of one's intellectual and moral value. Although such claims were considered true in several academic and other discourses (and thus achieved the status of dans le vrai), they were in fact false (and thus did not have the actual status of dire vrai). As noted earlier, this past notion of race is no longer the consensus view among social scientists, anthropologists, and scholars of race and ethnicity; yet the discourse regarding race as essentialized and fixed in biology, even though false, had a widespread and injurious impact upon American society. Lastly, a statement qualifying as dire vrai, can, paradoxically, be both true (dire vrai) and not true (dans le vrai). ${ }^{11}$ For example, the present widely accepted discourse regarding race as a social construction - a discourse that is today accepted as dire vrai would not have "shown up" as a potential candidate to consider. In other words, the acceptability conditions for such a discourse to be heard were not present as they are in contemporary academic discourses. In short, historically specific structuring (acceptability) conditions that function as historical a prioris have the ability, as it were, to silence true (dire vrai) propositions and discourses; that is, they can prevent true discourses from appearing at all. Thus, these muted or unarticulated discourses can and often have emerged in a subsequent historical period whose acceptability conditions allow new discourses not only to sound but also to be 
heard - a hearing that then allows for the possibility of judging their truth or falsity.

\section{Monson on Racialized Jazz Discourses and Saying Something Sonically}

Drawing upon Foucault's notion of discourse as, generally speaking, linguistically articulated ideas used to establish one's argument and to justify one's position, and which "possess the authority and prestige to order how we think about the world," Monson describes the multiple musical, cultural, and sociopolitical discourses and strategic practices operative in the world of jazz in America in the mid-twentieth century (2007, p. 24). In addition, Monson's Foucauldian-influenced account helps us to understand better why certain discourses about jazz emerged and why others did not (and could not) until a later period.

As Monson explains, jazz discourses of the 1940s-1960s had become overly binary and highly racialized. On the one hand, we find a liberal, universalist, colorblind discourse depicting jazz as neither black nor white but rather as "a colorblind art music open to all who master its repertory, improvisational mode of musical creation, and demand for individuality and originality" (Monson, 2007, p. 70). On the other hand, we find black and white musicians, scholars, critics, and supporters who reject the colorblind discourse and emphasize the African American origins of jazz; however, their arguments often presupposed and deployed an unhelpful, essentialized notion of blackness to articulate the constitutive esthetic elements of jazz. For many in the latter group, to insist on a colorblind discourse was just another variation on a long history of white confiscation of (and profiting from) black cultural contributions and innovations. Given the long history of racism, the exploitation of African American musicians, and the continuation (although in different forms) of entrenched racialized structures and unjust economic practices, one can understand why the discursive framework shaping jazz discourses had become so polarized well into the 1960s. Rather than an either/or - that is, jazz as either universal, colorblind, and untouched by history, or as ethnically particular and essentially black, Monson articulates a third way beyond this impasse. That is, she highlights the porousness and hybridity of jazz esthetics and demonstrates how the very construction of a jazz Afro-modernism not only represents an innovative and significant artistic contribution but also says something or signifies (in Gates's sense) in the sociopolitical realm. This 
signification occurs not only via the discourses surrounding jazz but also in the music itself, which communicates irony, humor, and sounds a critique of the unjust social, political, and economic system (see also, Floyd, 1995, Chapter 4; Monson, 1994).

For example, take John Coltrane's transformation of the popular Broadway tune, "My Favorite Things." Coltrane's "signification" upon the tune is a multiple-layered example of structural, harmonic, melodic, and rhythmic modifications. The modifications so alter the original tune that jazz esthetes - both black and white - acknowledge Coltrane's version as superior. As Monson explains, Coltrane's creation, "makes the interludes, not the verse, the subject of the performance; it transforms waltz time into a polyrhythmically textured six-feel; and it transforms a sentimental, optimistic lyric into a vehicle for a more brooding improvisational exploration" (1996, p. 116). Moreover, the Coltrane version carries within it and communicates (to those with ears to hear) ironic overtones. The new polyrhythmic groove and the protracted improvised solos re-write the lyrical images of "girls in white dresses," "snowflakes on eyelashes," and other "white things" and communicate a weighty, contemplative, and at times menacing feel. Given that Coltrane's version of the tune emerged during the years of the Civil Rights Movement, it is certainly possibile that Coltrane intended his musical interpretation to make an ironic and socially critical statement. Even if this was not the case, one need not limit the possible range of meanings of a musical work to the intentions of the composer(s). Just as the dynamic ontology of texts allows for multiple interpretations over time by different interpretative communities and traditions, the same is true with musical pieces. In addition to these examples of sonic irony, Monson highlights how Coltrane's transformation of "My Favorite Things" strategically employs European American musical standards for its own purposes. That is, by traditional standards of Western classical music, the original tune and arrangement would be judged as exceedingly basic and unoriginal. However, Coltrane's version with its sophisticated harmonic and rhythmic textures not only surpassed the original when judged by jazz esthetical standards but also illustrated how jazz musicians can "invoke selectively some of the hegemonic standards of Western classical music in their favor" (Monson, 1996, p. 120). Lastly, these strategic moves occur simultaneously with the creation of something new - an African American jazz esthetic that becomes an evaluative standard by which non-African American music and musicians are judged.

In order to demonstrate the hybridity of bebop, Monson highlights the multiple esthetic streams constituting jazz. These streams include: blues, 
gospel, R\&B, American popular songs (e.g., Tin Pan Alley), modern classical music, African and Afro-Cuban esthetics, and Indian, as well as other non-Western, esthetics (Monson, 2007, p. 71). What emerges from this creative and strategic harmonization is, as we have already noted via Ramsey, a new Afro-modernist esthetic - a new black modernist esthetic that was, on the one hand, "more populist than its European art music counterpart, and on the other, committed to articulating its elite position relative to the more commercial genres of $\mathrm{R} \& \mathrm{~B}$ and rock and roll" (Monson, 2007, p. 71). Thus, the creative artistry and sociopolitical astuteness of bebop musicians like Gillespie, Parker, and a host of others actively defined the "aesthetic center of this canonic period in jazz," transforming and bringing into existence an Afro-esthetic - a "blackening of modern aesthetics, which would ultimately serve as a standard against which any player of jazz would be evaluated" (Monson, 2007, p.71).

On this model, African American jazz musicians such as Gillespie, Parker, Davis, Coltrane, and others are acknowledged as the creative innovators whose standard-setting contributions and leadership made bebop and continues to exert significant influence on contemporary jazz musicians. However, this model starts with and employs a view of race and esthetics as socially constructed rather than "natural" and fixed. ${ }^{12}$ Although structures and discourses can become entrenched and can impute meanings to physical characteristics (in the case of "race," phenotypic markers) and musical features (in the case of jazz, syncopated rhythms), such meanings are open to change over time as practices "on the ground" work to change the discourses and structures. Thus, by rejecting an essentialistinformed and hence fixed notion of bebop's Afro-modernist esthetic, one can acknowledge its hybridity and avoid overly rigid and often stereotypical definitions of "authentic" black music - stereotypes that all too often fail to acknowledge the extensive esthetic range of African American musicians. Yet this model also allows one to draw attention to the differences in lived experience between white and black jazz musicians given the institutional and structurally racist system. For example, due to structural white privilege, white jazz musicians, many of whom were talented and acknowledged as so by their black counterparts, received the highest paying gigs and widespread and sustained press coverage in jazz and other publications, and were granted disproportionate radio and television performance opportunities in comparison to black musicians. Likewise, many black jazz players whose talents surpassed their white counterparts were not only denied prestigious performance opportunities but also regularly subject to unjust, disdainful, and even violent treatment both onstage and offstage 
and especially when touring in southern states. Here Monson emphasizes an important distinction between an "individual's self-conscious identity (whether ethnic or political) and that person's treatment as a citizen within the larger sociology of race relations in the United States" (2007, p. 73). A white, liberal progressive may possess a heightened ethnic consciousness and have no intentional desire to benefit from white privilege; nonetheless, he or she does in fact benefit daily from racially skewed sociopolitical and economic structures. Similarly, whether white or black, a musician can choose and develop skills allowing him or her to participate in multiple musical esthetics, styles, and traditions; however, exercising one's "aesthetic agency" and achieving recognizable musical skills does not by itself change the larger sociopolitical and economic structures. Policies, legislation, cultural, and other discourses must also change. This is not to negate an individual's esthetic choices; it is, however, to acknowledge the complexity of the structural strata constituting society and the fact that structures change at a much slower rate than practices and require transformations from multiple spheres.

\section{CONCLUSION}

In this chapter, I have argued that jazz esthetics and inflections of jazz such as bebop are socially conditioned, dynamic, and hybrid in character. To affirm the fluid and hybrid character of jazz, bebop, and Afro-modernist esthetics neither renders impossible our ability to identify discernible features of particular styles and esthetic traditions nor requires that we accept a colorblind discourse about jazz. Rather, my model, following Monson and a host of others, affirms that sociopolitical, cultural, legal, and economic structures and practices influence and condition all types of music-making. Bebop as an inflection of Afro-modernism is of course no exception. In fact, I have emphasized that in order to have a historically rich and comprehensive understanding of bebop, one must consider the social, political, and highly racialized context in which this music (and its discourses) emerged. To neglect the sociopolitical import of bebop is to display one's ignorance of the African American signifyin(g) tradition. Moreover, it is, as Lott puts it, to fail to see that the "self-conscious advances of bebop" are part of "a moment, the early forties, in which unpaid historical bills were falling due" (Lott, 1988, p. 587). 


\section{NOTES}

1. Admittedly, I have already set up an artificial binary with my discourse of white and black. Other ethnicities, groups, and esthetical traditions likewise contributed to the sociopolitical struggles of the period and to the ongoing creation of various jazz styles (e.g., Afro-Cuban and West Indian influences).

2. Of course, these "discernible features" are themselves hybrid in nature having arisen from multiple musical genealogies, practices, and appropriations.

3. Monson further explains how these binary impositions "collapsed ethnic and cultural distinctions within populations of African descent" (e.g., Caribbean populations and Creoles populations in Louisiana) and likewise flattened and masked the ethnic diversity among European immigrant groups (2007, p. 9).

4. One could argue that other animals such as birds also create music. To an extent, I certainly agree. However, I would argue that the level of harmonic, melodic, and rhythmic complexity, the double-voicedness, and the strategic and political intentional purposes of both the instrumental and vocal music I examine in the present study are distinctively human cultural products.

5. Monson provides a helpful analysis of the political context and message of Max Roach's work, Freedom Now Suite, and the sociopolitical ideals and philosophies that inspired both Roach and Abby Lincoln (Monson, 2007, see esp. pp. 171-181).

6. Ramsey discusses several mid-twentieth century "processes and their contradictions and paradoxes" including: mass migration, the (mis)use of black bodies, an emerging black defiance that helped to fuel effective political strategies and collective actions, and lastly, the multiple and "conflicting discourses on art's role in social change" (2003, p. 98, see also, Chapter 5, "We Called Ourselves Modern," esp. pp. 98-105).

7. For a discussion of the resistance elements of bebop within the marketplace, see DeVeaux (1997, esp. pp. 20-27).

8. For a theoretical analysis deconstructing the assumed rigid dichotomy between composition and improvisation, see Nielsen (2009).

9. DeVeaux sums up this process nicely: "Notation imposes upon music the idea of a permanent text to which authorship can safely be ascribed and ownership securely established. Such fixity is a necessary precursor to commodification" (1997, p. 10).

10. The federal copyright laws were amended in the 1970s to cover recordings. See, Monson (2007, p. 336, no. 2). See also, DeVeaux (1997, esp. pp. 11-12). As DeVeaux explains, the growing ascendancy of recordings over sheet music did not change the economic privileges and power structures. "[E]conomic power remained stubbornly in the grip of music publishers, who insisted (with the help of copyright law) that all financial benefits to creativity must flow to officially recognized composers. Since royalties for performance per se were relatively rare (contracts typically dictated a modest one-time fee), 'mere' performers saw very little of this money, unless they somehow managed to claim the role of composer" (p. 12).

11. It is also the case that a statement can be false and yet true (dans le vrai); such was the case with the aforementioned dominant view of race as a 
bio-behavioral racialized essence in the nineteenth century. It passed the "acceptability test," yet it was clearly false.

12. Monson's model and mine share many similarities such as our affirmation of the hybridity and dynamism of jazz esthetics as well as its socially conditioned character. Likewise, we both emphasize the innovative and standard-setting contributions of African American musicians in creating and developing jazz and bebop in particular.

\section{REFERENCES}

DeVeaux, S. (1997). The birth of bebop. A social and musical history. Berkeley, CA: University of California Press.

Floyd, Jr., S. A. (1995). The power of black music: Interpreting its history from Africa to the United States. New York, NY: Oxford University Press.

Foucault, M. (1972). The archaeology of knowledge and the discourse on language (A. M. Sheridan Smith, Trans.). New York, NY: Pantheon.

Foucault, M. (2007). What is critique? In S. Lotringer (Ed.), The politics of truth (pp. 41-81). Los Angeles, CA: Semiotext(e).

Gates, Jr., H. L. (1988). The signifying monkey. A theory of African American Literary Criticism. Oxford: Oxford University Press.

Kelly, R. D. G. (1997). Dig they freedom. Meditations on history and the black avant-garde. Lenox Avenue: A Journal of Interarts Inquiry, 3, 13-27.

Khanna, N. (2010). If you're half black, you're just black: reflected appraisals and the persistence of the one-drop rule. The Sociological Quarterly, 51, 96-121, esp. pp. 98-101.

Lott, E. (1988). Double V, double-time: Bebop's politics of style. Callaloo, 36, 597-605.

Monson, I. (1994). Doubleness and Jazz Improvisation: Irony, Parody, and Ethnomusicology. Critical Inquiry, 20, 283-313.

Monson, I. (1996). Saying something. Jazz improvisation and interaction. Chicago, IL: University of Chicago Press.

Monson, I. (2007). Freedom sounds. Civil rights call out to jazz and Africa. Oxford: Oxford University Press.

Nielsen, C. (2009). What has Coltrane to do with Mozart: The dynamism and built-in flexibility of music. Expositions, 3, 57-71.

Radano, R. (2010). On ownership and value. Black Music Research Journal, 30, 363-369.

Ramsey, G. (2003). Race music: Black cultures from bebop to hip-hop. Berkeley, CA: University of California Press.

Thomas, L. (1995). Ascension: Music and the black arts movement. In K. Gabbard (Ed.), Jazz among the discourses (pp. 256-274). Durham: Duke University Press.

Thompson, K. (2008). Historicity and transcendentality: Foucault, Cavailles, and the phenomenology of the concept. History and Theory, 47, 1-18. 